\title{
Propiedades físicas y mecánicas del hormigón usando polvo residual de desechos orgánicos como reemplazo parcial del cemento
}

\section{Physical and Mechanical Properties of Concrete Using Residual Powder from Organic Waste as Partial Cement Replacement}

\author{
I. Soto Izquierdo ${ }^{1}$, O. Soto Izquierdo*, M. Ramalho ${ }^{* *}$
}

* Universidade Federal do Tocantins, Tocantins. BRAZIL

** Universidade de São Paulo, São Paulo. BRAZIL

Fecha de Recepción: 06/08/2018

Fecha de Aceptación: 30/10/2018

PAG 229-240

\begin{abstract}
The continued growth in demand for cement has raised concerns in the industry about environmental and sustainability issues. In addition, the worldwide generation of large quantities of solid waste threatens human health and on environmental quality. This paper proposes to assess the feasibility of using a residual powder derived from organic waste of vegetable or animal origin for replacing part of Portland cement during concrete production. Specifically, the powder is derived from a living being such as the remains of food (meat, vegetables, fruits and eggshells), paper, wood, bones and seeds. Its scientific contribution is a conscious change due to development of an alternative material to contribute with more sustainable processes in the construction industry. Three types of mixtures for cement content were studied: aggregate/cement $(A / C)$ ratios of 15, 10 and 6. Concrete samples were then made by replacing the cement with organic waste powder in percentages of $5 \%, 10 \%, 15 \%$, and 20\%. These mixtures were evaluated for their physical and mechanical properties. The results showed that the reference concrete had higher compressive strength than the concrete with low cement content (A/C ratio of 15:1). However, samples made with $5 \%$ of powder and an A/C ratio of 10:1 presented values at least $2.1 \%$ greater than compressive strength of the reference concrete. Mixtures rich in cement $(A / C$ ratio of $6: 1)$ and the powder replacements of up to $10 \%$ showed in the best mechanical behavior in $13 \%$ in relation to the reference concrete. Therefore, waste powder can be used as filling material to replace part of the cement, resulting in denser and more resistant concrete, as well as less specific absorption and voids.
\end{abstract}

Keywords: Residual powder, organic waste, concrete, mechanical properties

\section{Resumen}

Actualmente, el crecimiento continuo en la demanda de cemento genera preocupaciones ambientales y de sostenibilidad en la industria cementera. Por otra parte, la generación de grandes cantidades de residuos sólidos urbanos a nivel mundial provoca daños en la salud humana y en la calidad del medio ambiente. Por lo anterior, esta investigación propone evaluar la sustitución parcial del cemento Portland por un polvo residual obtenido de la descomposición química de residuos orgánicos de origen vegetal o animal, tales como restos de alimentos (carne, vegetales, frutas, cáscara de huevo), papel, madera, huesos y semillas. De esta forma, una contribución científica podría generar un cambio consciente en el desarrollo de un producto como material alternativo que contribuya con procesos más sostenibles en la industria de la construcción. Se estudiaron tres tipos de mezcla, variando el contenido de cemento, seleccionando las proporciones agregados/cemento (a/c) de 15, 10 y 6 . Se prepararon hormigones sustituyendo el cemento por el polvo de residuo orgánico, en peso, en porcentajes de 5, 10, 15 y $20 \%$. Se evaluaron sus propiedades físicas y mecánicas. Los resultados mostraron que el hormigón de referencia presentó mayor resistencia a la compresión que el hormigón con bajo contenido de cemento (proporción a/c de 15:1). Sin embargo, las mezclas preparadas con un 5\% de polvo y razón a/c de 10:1 presentaron valores, de al menos, 2,1\% superiores a la resistencia a la compresión del hormigón de referencia. Las mezclas ricas en cemento (razón a/c de 6:1) con reemplazo de polvo de hasta un $10 \%$ mostraron un mejor desempeño mecánico, 13\% superior en relación al hormigón padrón. En consecuencia, se puede usar el polvo orgánico como material de relleno (filler) en el hormigón para sustituir parte del cemento puesto que se obtienen hormigones más resistentes y densos y con menor absorción específica e índice de vacíos.

Palabras clave: Polvo residual, residuo orgánico, hormigón, propiedades mecánicas

\section{Introduction}

Economic growth creates the need for investments in infrastructure. This, in turn, increases the demand for services in the construction market. Concrete consumption has proportionally increased with the growing economies and,

\footnotetext{
1 Corresponding author:

Universidade Federal do Tocantins (UFT), Tocantins, Brazil

E-mail: indaritasi@uft.edu.br
}

consequently, there is a growing global demand for cement. Cement production consumes $12-15 \%$ of total world energy and is responsible for $7 \%$ of $\mathrm{CO}_{2}$ emissions across the planet, contributing to global warming (Ali et al., 2011). $\mathrm{CO}_{2}$ emissions in cement production are primarily due to the decomposition of carbonates into oxides present in the limestone. In order to reduce $\mathrm{CO}_{2}$ emissions, the cement industry has considered several measures for the reduction of clinker content. They include replacing it with waste materials like silica fume, fly ash, or blast furnace slag, and its use as an alternative raw materials.

The generation of large quantities of municipal solid waste (MSW) is a major worldwide environmental problem 
(Bernardes et al., 2008). Disposal in landfills has been a simple and inexpensive method for discarding waste. However, this solution has resulted in the pollution of surface and groundwater, unpleasant odors, and soil contamination. Similarly, spaces for landfills are becoming limited, especially in countries with large populations (Saikia et al., 2007). Alternative methods for the treatment of solid waste include incineration, the recycling of reusable materials, and the chemical processing of organic waste.

At present, the incineration of MSW is one of the most frequently used measures in industrialized countries. The process reduces the volume of urban waste up to $90 \%$ and allows the generation of energy (Shi \& Kan, 2009). In general, different types of ash are generated in the MSW incineration process which will depend on the compositions of the solid residue. These vary over time and from country to country due to differences in lifestyle. The ash byproduct of incineration is equivalent to $2-5 \%$ of municipal waste. Thus, large quantities of incinerated ash are produced each year, requiring suitable destinations for disposal. According to Guo et al. (2014), the primary chemical components of ash belong to the groups of $\mathrm{CaO}-\mathrm{SiO}_{2}-\mathrm{Al}_{2} \mathrm{O}_{3}-\mathrm{SO}_{3}$ and can be used as replacement for cement. Thus, several researchers have studied the use of ash in the production or replacement of cement. In the research by Saikia et al. (2007), the use of ash in the production of cement clinker allows a reduction of up to $20 \%$ of $\mathrm{CaCO}_{3}$, which can reduce $\mathrm{CO}_{2}$ emissions. Ferraris et al. (2009) used the ash as filler to replace part of the cement. The concentrations used were $0 \%, 25 \%, 50 \%$, $75 \%$, and $100 \%$ by volume, with a water/cement ratio of 0.60 for the production of mortars and concretes. The results showed that the substitution of the filler up to $25 \%$ did not affect the compressive strength of concrete. Wu et al. (2012) evaluated the replacement of incinerated ash in the production of Portland cement. The results showed that the replacement of $30 \%$ of the ash could be used for the production of Portland cement. However, heavy metals may be present in the form of fly ash or vapor in flue gas, which is the main concern for its potential use as a raw materials in the production of clinker and other products.
One practical alternative for waste disposal is through decomposition by chemical reaction. For now, this chemical process is only performed in organic waste and has been studied by many researchers, including Carneiro (2013), Goyal et al. (2005), and Kejun et al. (2011). The product of the decomposition process is a powder that can be re-used as a construction material.

This study assessed the potential use of residual powder from organic waste as a replacement for cement. The residue is obtained from the urban waste that is received by the truck and placed on a selection mat with magnetic roller for the extraction of the metallic material. Through the manual selection all inorganic materials, such as wood, glass, plastic, rubber, batteries etc., are removed, leaving basically the organic residues. According to the NBR 10004: 2004, this waste may be classified as "Non-Hazardous Waste - Class II A - Inerts". We evaluated the use of residual powder in concrete with the aggregate/cement (A/C) ratios of 15:1, 10:1, and 6:1 (low, medium, and high cement consumption, respectively) by weight. Residual powder percentages in the cement were $5 \%, 10 \%, 15 \%$, and $20 \%$. At first, it was necessary to characterize the powder by means of energy dispersive $X$-ray spectroscopy (EDS) and scanning transmission electron microscopy (SEM) to determine the chemical composition. Solubility and leachability tests were also done to determine if the residue was an inert and noncontaminating material that is suitable for use in the cement matrix. It is possible to offer an alternative to the disposal of organic waste by transforming it into a reusable powder.

\section{Experimental program}

\subsection{Material characterization \\ 2.1.1 Portland cement}

This study used Portland cement with a high early strength (Brazilian type CPV-ARI). It was commercially available in Brazil. The mechanical and physical properties of the cement taken from the supplier are summarized in Table 1.

Table 1. Mechanical and physical properties of the cement (Self-Elaboration)

\begin{tabular}{|l|l|}
\hline \multicolumn{1}{|c|}{ Properties } & \multicolumn{1}{c|}{ Results } \\
\hline Specific gravity $\left(\mathrm{g} / \mathrm{cm}^{3}\right)$ & 3.12 \\
\hline Blaine specific surface $\left(\mathrm{cm}^{2} / \mathrm{g}\right)$ & $4,743.00$ \\
\hline Initial setting time $(\mathrm{min})$ & 110 \\
\hline Final setting time $(\mathrm{min})$ & 163 \\
\hline Volume expansion $(\mathrm{mm})$ & 3 \\
\hline 3 days Compressive strength $(\mathrm{MPa})$ & 44.40 \\
\hline 7 days Compressive strength $(\mathrm{MPa})$ & 47.90 \\
\hline 28 days Compressive strength $(\mathrm{MPa})$ & 52.20 \\
\hline
\end{tabular}




\subsubsection{Fine aggregates}

The fine aggregates used included sand and stone powders. These were based on calcareous. The characterization of the fine aggregates met the requisites of Brazilian standards and showed the following results: specific gravity (NBR NM 52, 2009) of $2620 \mathrm{~kg} / \mathrm{m}^{3}$ and $2890 \mathrm{~kg} / \mathrm{m}^{3}$; bulk density (NBR NM 45, 2006) of $1680 \mathrm{~kg} / \mathrm{m}^{3}$ and 1720 $\mathrm{kg} / \mathrm{m}^{3}$; and water absorption (NBR NM 30, 2001) of $0.87 \%$ and $1.02 \%$, respectively. According to Brazilian standard (NBR 7211, 2009), the sand could be classified as fine sand in Zone 2 and the stone powder classified as coarse sand in Zone 4.

\subsubsection{Coarse aggregate}

The coarse aggregate was the basalt gravel. The characterization of the coarse aggregate showed the following results: specific gravity (NBR NM 53, 2009) of $2860 \mathrm{~kg} / \mathrm{m}^{3}$; bulk density (NBR NM 53, 2009) of $2700 \mathrm{~kg} / \mathrm{m}^{3}$; and maximum characteristic dimension (NBR NM 248, 2003) of $9.50 \mathrm{~mm}$.

\subsubsection{Residual powder from organic waste}

Residual powder from the organic waste was analyzed using EDS and SEM to determine its chemical composition and particle size. The samples were completely flat with resin immersed and it was used carbon as coating-type material. Its heavy metal content, specific surface area, specific gravity, and sieve content were analyzed according to Brazilian standards NBR 10004, 2004; NBR NM 248, 2003; NBR NM 23, 2001; and NBR 11579, 2012; respectively.

The organic waste was separated from the solid waste and passed through a crusher where the material was ground up. It was then transferred to a chamber where chemical products such as virgin lime and chlorine were applied to eliminate fatty waste, manure, methane gas, animal and human waste, and chemically encapsulate heavy metals. After the chemical process, the resulting mass was heated in an oven to a temperature of $300^{\circ} \mathrm{C}$. Then, it was converted to a powder by means of micronization with the use of a mill with compressed air for 20 minutes. The milling is due to the shock between the particles of the product itself, which, receiving the energy of the compressed air, gains speeds of up to $500 \mathrm{~m} / \mathrm{sec}$. With the impact and the grinding time, the particles decrease in size until reaching the desired quality.

\subsection{Mix proportion and analysis of concretes}

Table 2 shows details of the mixtures for each $A / C$ ratio studied. The moisture content was set at $6.0 \%$, and the percentage of organic admixtures for all concrete was maintained at a constant $0.35 \%$. In the research was used organic admixtures Glenium ${ }^{\circledR} 160$ SCC, a product developed by BASF for the production of self-compacting concrete and high performance concrete. It is based on a modified polycarboxylic ether chain, providing water reduction. Glenium $^{\circledR} 160$ SCC has a light brown color, has an average density of $1.11 \mathrm{~g} / \mathrm{cm}^{3}$ and an average solids content of $40 \%$, according to the manufacturer.

Table 2. Mix proportion for $1 \mathrm{~m}^{3}$ of concrete (Self- Elaboration)

\begin{tabular}{|l|l|l|l||}
\hline \multirow{2}{*}{ Materiais } & \multicolumn{3}{c|}{ Aggregate/cement ratios } \\
\cline { 2 - 4 } & $\mathbf{1 5 : 1}$ & $\mathbf{1 0 : 1}$ & $\mathbf{6 : 1}$ \\
\hline Cement $(\mathrm{kg})$ & 141 & 205 & 322 \\
\hline Coarse aggregate $(\mathrm{kg})$ & 846 & 820 & 773 \\
\hline Sand $(\mathrm{kg})$ & 508 & 492 & 696 \\
\hline Stone dust $(\mathrm{kg})$ & 761 & 738 & 464 \\
\hline $\mathrm{H}_{2} \mathrm{O}(\mathrm{kg})$ & 143.80 & 143.60 & 144.90 \\
\hline W/C & 1.02 & 0.70 & 0.45 \\
\hline Content of mortar (\%) & 62.50 & 63.60 & 65.70 \\
\hline $\begin{array}{l}\text { Additive in relation to the mass of } \\
\text { Cement }(\%)\end{array}$ & 0.35 & & \\
\hline Moisture $(\%)$ & 6.00 & & \\
\hline
\end{tabular}


To investigate the viability of residual powder as a cement replacement in concrete, five mixtures were produced for each A/C ratio. The contents of substitution by weight were 5, 10, 15, and 20\%. Table 3 shows the nomenclature for each type of concrete.

Table 3. The nomenclature for each type of concrete. (Self-Elaboration)

\begin{tabular}{|l|l|l|l|l|l|}
\hline \multirow{2}{*}{ A/C } & \multicolumn{5}{|c|}{ Ratio of organic residual powder substituting the cement } \\
\cline { 2 - 6 } & $\boldsymbol{0} \%$ & $\mathbf{5 \%}$ & $\mathbf{1 0} \%$ & $\mathbf{1 5 \%}$ & $\mathbf{2 0} \%$ \\
\hline $15: 1$ & $15-R E F$ & $15-R . P 5$ & $15-R . P 10$ & $15-R . P 15$ & $15-R . P 20$ \\
\hline $10: 1$ & $10-R E F$ & $10-R . P 5$ & $10-R . P 10$ & $10-R . P 15$ & 10-R.P20 \\
\hline $6: 1$ & 6-REF & 6-R.P5 & 6-R.P10 & 6-R.P15 & 6-R.P20 \\
\hline
\end{tabular}

Cylindrical samples with a diameter of $50 \mathrm{~mm}$ and a height of $100 \mathrm{~mm}$ were used for the analysis of the concrete's properties in hardened state. The samples were exposed to a temperature of $23 \pm 2{ }^{\circ} \mathrm{C}$ and a relative humidity of $90 \pm 5 \%$ inside a chamber. Analysis of the concrete's bulk density, water absorption by immersion, and voids index were conducted according to Brazilian standard (NBR 9778, 2005) in five samples for each type of concrete (15 mixtures, totaling 75 samples) at an age of 28 days. Compressive strength was determined according to Brazilian standard $(N B R 5739,2007)$ in eight samples for each type of concrete (totaling 120 samples) at an age of 28 days. Tests were conducted using a computerized machine (ELE) with an Autotest model 2000. The machine's capacity was 2000 kN using power control at a constant speed of $2.03 \mathrm{kN} / \mathrm{s}$.

\section{Results and discussion}

\subsection{Organic residual powder}

Figue 1 shows images of several samples of the waste powder using SEM. The residue displayed heterogeneity in the form of particles due to the circular or lamellar aspect of the grains.

Measurements of particle size using the Image I program are summarized in Table 4. We noted varying sizes in the samples, which was favorable because the material can occupy the largest volume of space, favoring the packaging of the cement paste.

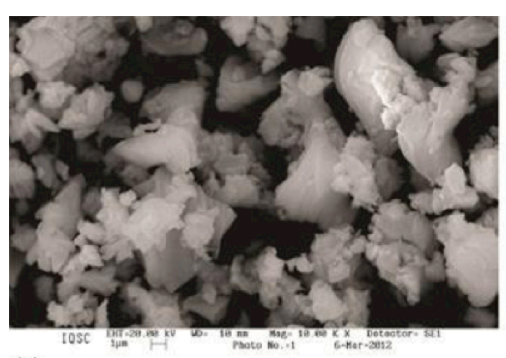

(a)

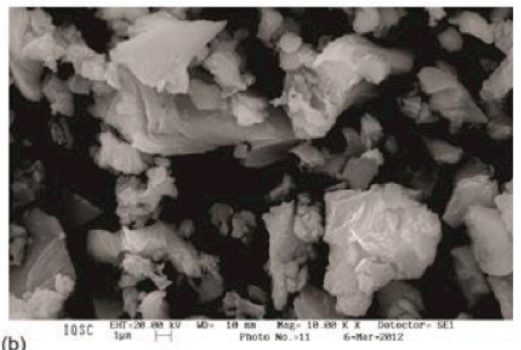

(b)

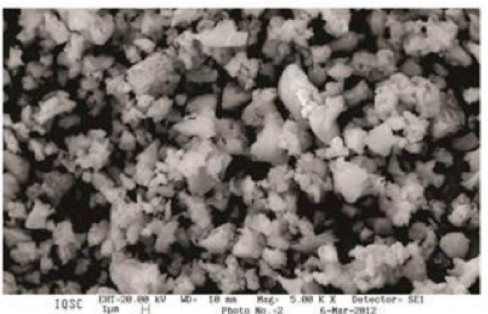

(c)

Figure 1. SEM images of the organic residual powder: (a) sample 1, (b) sample 2, and (c) sample 3. (Self-Elaboration) 
Table 4. Particle size of the organic residual powder. (Self-Elaboration)

\begin{tabular}{|c|c|c|c|}
\hline & $\begin{array}{c}\text { Sample 1 } \\
(\boldsymbol{\mu m})\end{array}$ & $\begin{array}{c}\text { Sample 2 } \\
(\boldsymbol{\mu m})\end{array}$ & $\begin{array}{c}\text { Sample 3 } \\
(\boldsymbol{\mu m})\end{array}$ \\
\hline & 3.88 & 2.94 & 4.56 \\
\hline & 3.50 & 4.36 & 6.37 \\
\hline & 5.03 & 2.08 & 3.82 \\
\hline & 5.31 & 2.75 & 2.79 \\
\hline & 1.89 & 5.27 & 7.31 \\
\hline & 2.18 & 2.26 & 3.69 \\
\hline & 2.89 & 2.95 & 2.16 \\
\hline & 1.75 & 1.59 & 1.34 \\
\hline & 2.74 & 2.07 & 1.47 \\
\hline & 1.70 & 2.89 & 1.84 \\
\hline & 5.46 & 1.63 & 2.13 \\
\hline & 5.17 & 3.06 & 1.69 \\
\hline & 2.95 & 4.56 & 3.95 \\
\hline & 3.28 & 3.16 & 3.26 \\
\hline
\end{tabular}

The chemical analysis was conducted using EDS. Figure 2 illustrates the EDS spectra of three organic residual powder samples.
Elements present in a lower proportion included sodium, magnesium, aluminum, silicon, phosphorus, sulfur, and chlorine. The most abundant elements were carbon, oxygen, and calcium.

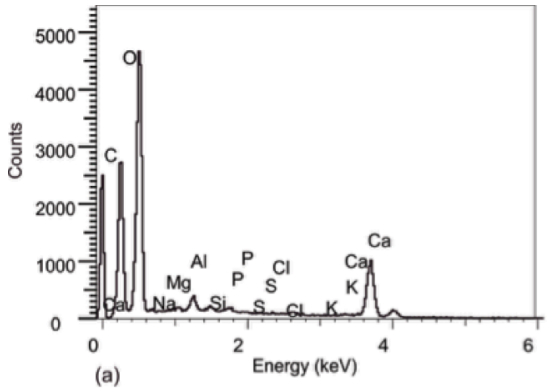

(a)
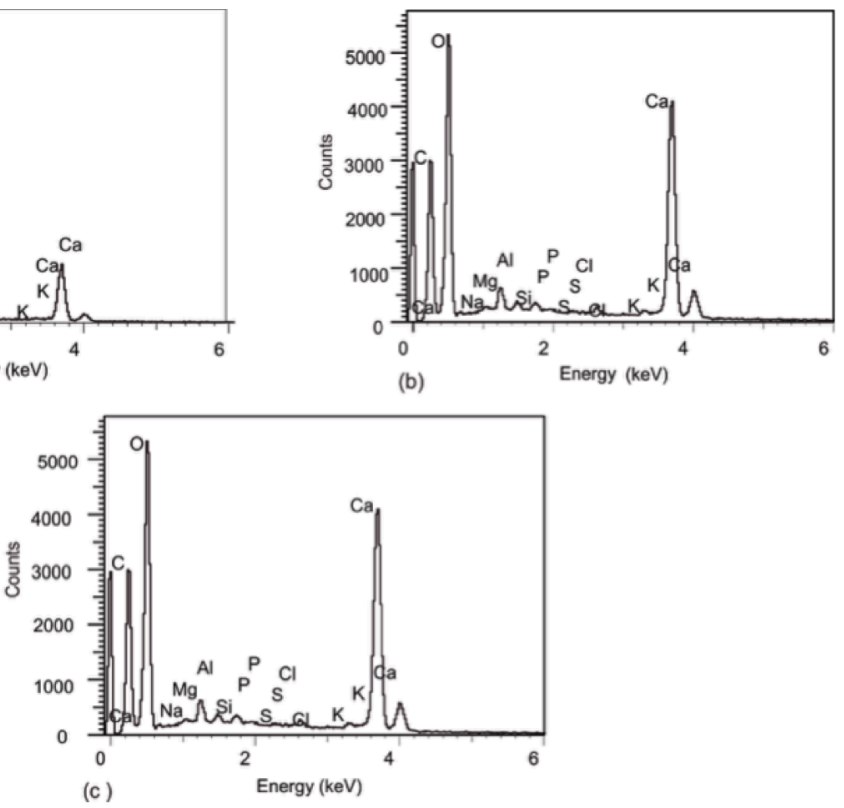

Figure 2. EDS spectra of three different samples of organic residual powder: (a) sample 1, (b) sample 2, and (c) sample 3. (Self-Elaboration) 
Table 5 shows the metals analyzed in the residual powder samples. The nomenclature $<L O D$ means that the concentration was very low and not capable of being accurately quantified. According to Brazilian standard (NBR 10004, 2004), elements considered dangerous due to their toxicity included chromium, arsenic, cadmium, lead, and mercury in very low concentrations. Those concentrations comply with the limits imposed by the standard. As a result, the residual powder was clean and free of all contamination and classified as not hazardous. It would be possible, therefore, to dispose of these substances in an environmentally friendly and sustainable manner.

With respect to the physical characterization, the residual powder had a specific surface of $4370 \mathrm{~m}^{2} / \mathrm{g}$, specific gravity of $720 \mathrm{~kg} / \mathrm{m}^{3}$, fineness-retained \#200 of $0.20 \%$ and fineness-retained \#325 of $1.50 \%$.

Table 5. Heavy metals present in the organic residual powder. (Self-Elaboration)

\begin{tabular}{|c|c|c|}
\hline Metals & $\begin{array}{c}\text { Values } \\
(\mathbf{m g} / \mathbf{l})\end{array}$ & $\begin{array}{c}\text { Maximum Limit } \\
(\mathbf{m g} / \mathbf{l})\end{array}$ \\
\hline Copper & 7.76 & - \\
\hline Chrome & $<L O D$ & 5.0 \\
\hline Arsenic & $<L O D$ & 1.0 \\
\hline Cadmium & $<L O D$ & 0.5 \\
\hline Lead & $<L O D$ & 1.0 \\
\hline Cobalt & $<L O D$ & - \\
\hline Phosphorus & 72.59 & - \\
\hline Nickel & $<L O D$ & - \\
\hline Zinc & 15.41 & - \\
\hline Mercury & $<L O D$ & 0.1 \\
\hline
\end{tabular}


include the mean, standard deviation $(S d)$, and coefficient of variation $(\mathrm{CV})$.

The Figure 3 shows the graphs of each mixture studied allowing a better interpretation of the results of the physical properties of the concrete.

Table 6. Physical characterization of the hardened concrete. (Self- Elaboration)

\begin{tabular}{|c|c|c|c|c|c|c|c|c|c|}
\hline \multirow{3}{*}{ Concretes } & \multicolumn{3}{|c|}{$\begin{array}{c}\text { Specific density - hardened } \\
\text { state }\left(\mathrm{g} / \mathrm{cm}^{3}\right)\end{array}$} & \multicolumn{3}{|c|}{ Water absorption (\%) } & \multicolumn{3}{|c|}{$\begin{array}{l}\text { Air void content - } \\
\text { hardened state }(\%)\end{array}$} \\
\hline & Mean & $S d$ & $C V(\%)$ & Mean & $S d$ & $C V(\%)$ & Mean & Sd & $\begin{array}{l}C V \\
(\%)\end{array}$ \\
\hline & \multicolumn{9}{|c|}{ Aggregate/cement ratio of 15:1 } \\
\hline 15-REF & 2.71 & 0.03 & 1.26 & 6.39 & 0.27 & 4.27 & 10.86 & 0.56 & 5.21 \\
\hline 15-R.P5 & 2.69 & 0.03 & 1.06 & 6.42 & 0.32 & 4.98 & 10.82 & 0.52 & 4.80 \\
\hline 15-R.P10 & 2.66 & 0.03 & 1.19 & 6.47 & 0.25 & 3.86 & 10.69 & 0.59 & 5.52 \\
\hline 15-R.P15 & 2.62 & 0.04 & 1.36 & 6.54 & 0.31 & 4.74 & 9.98 & 0.57 & 5.71 \\
\hline 15-R.P20 & 2.59 & 0.03 & 1.30 & 6.61 & 0.36 & 5.44 & 9.75 & 0.61 & 6.25 \\
\hline \multicolumn{10}{|c|}{ Aggregate/cement ratio of 10:1 } \\
\hline 10-REF & 2.78 & 0.05 & 1.88 & 5.81 & 0.29 & 4.96 & 10.85 & 0.49 & 4.55 \\
\hline 10-R.P5 & 2.80 & 0.05 & 1.67 & 5.76 & 0.30 & 5.25 & 10.81 & 0.45 & 4.16 \\
\hline 10-R.P10 & 2.77 & 0.05 & 1.88 & 5.80 & 0.33 & 5.62 & 10.86 & 0.50 & 4.60 \\
\hline 10-R.P15 & 2.74 & 0.05 & 1.85 & 6.02 & 0.33 & 5.54 & 10.92 & 0.41 & 3.75 \\
\hline 10-R.P20 & 2.69 & 0.05 & 1.68 & 6.24 & 0.32 & 5.05 & 11.11 & 0.46 & 4.14 \\
\hline \multicolumn{10}{|c|}{ Aggregate/cement ratio of $6: 1$} \\
\hline 6-REF & 2.81 & 0.05 & 1.82 & 5.01 & 0.28 & 5.58 & 9.98 & 0.47 & 4.72 \\
\hline 6-R.P5 & 2.84 & 0.05 & 1.83 & 4.96 & 0.31 & 6.25 & 9.86 & 0.49 & 4.97 \\
\hline 6-R.P10 & 2.82 & 0.05 & 1.75 & 4.98 & 0.29 & 5.82 & 9.89 & 0.42 & 4.25 \\
\hline 6-R.P15 & 2.78 & 0.06 & 1.99 & 5.09 & 0.32 & 6.28 & 10.08 & 0.46 & 4.56 \\
\hline 6-R.P20 & 2.75 & 0.05 & 1.76 & 5.15 & 0.27 & 5.24 & 10.67 & 0.50 & 4.68 \\
\hline
\end{tabular}




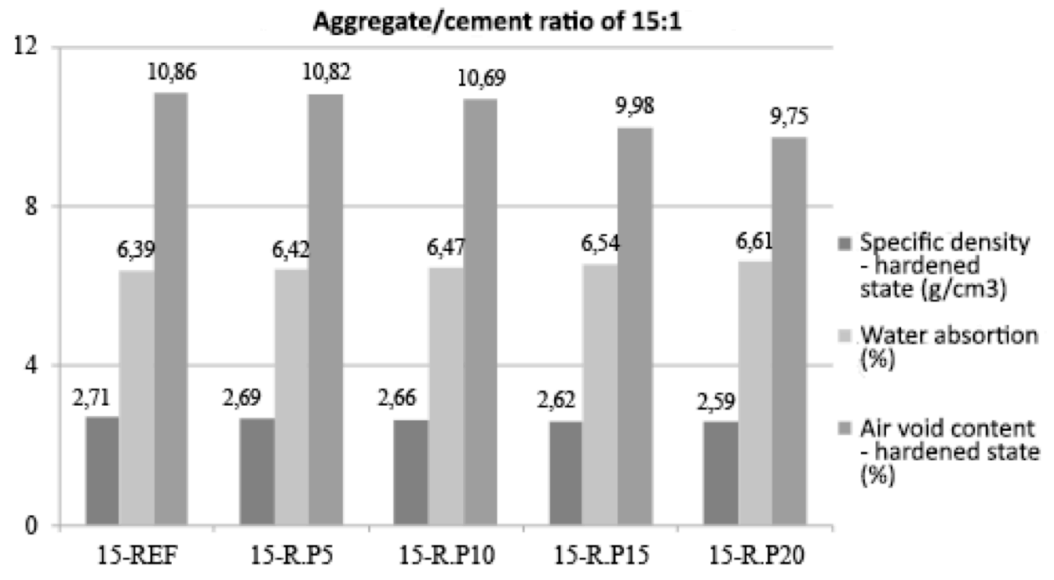

(a)

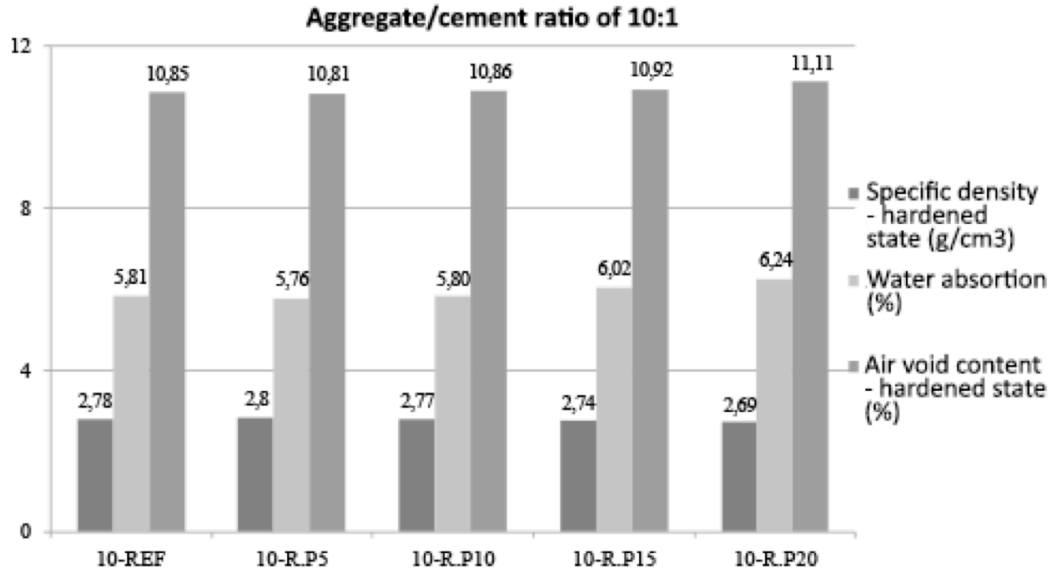

(b)



(c)

Figure 3. Physical properties of concrete: (a) $15: 1 \mathrm{~A} / \mathrm{C}$ ratio, (b) 10:1 A/C ratio, (c) 6:1 A/C ratio. (Self- Elaboration) 
Tests of samples with the $6: 1 \mathrm{~A} / \mathrm{C}$ ratio showed the highest values for density. Test samples with the 10:1 and 15:1 ratios had lower values for absorption and voids. We concluded that the increase in consumption of cement in the mixture was proportional to higher absorption and lower specific mass and voids.

In the 15:1 mixture, the waste powder did not cause improvements in the results. Values for specific gravity in the modified concrete were lower; and the values for water absorption and air void content were higher in relation to the reference concrete. For samples with an A/C ratio of 10:1, concrete with a content of $5 \%$ waste powder had a higher specific mass, as well as lower absorption and voids compared with concrete without added powder. Mixtures that consumed the most cement and with percentages of $5 \%$ and $10 \%$ reflected the best values for physical properties. Therefore, these concretes with the best performance had a higher density and lower water absorption and air void content due to the refinement of the pores in the cement paste.
According to results obtained in the 10:1 and 6:1 mixtures, several researches, such as Lagerblad and Vogt (2008) and Vogt (2010) have shown that the use of fillers replacing part of the cement bring improvements in the physical properties of hardened concrete, such as higher specific mass and lower void content due to better packaging in the mix.

Elyamany et al. (2014) evaluate the effect of various filler types on the fresh and hardened properties of concrete. The test results showed that the filler type has a significant effect on water absorption. The used non-pozzolanic fillers lower water absorption and voids ratio compared with pozzolanic fillers by $10 \%$

\subsection{Compressive strength of concrete}

For compressive strength, Table 7 shows the mean, standard deviation, and the coefficient of variation for concrete in each of the $A / C$ ratios.

Table 7. Compressive strength of the concrete for each aggregate/cement ratio. (Self-Elaboration)

\begin{tabular}{|l|c|c|c|}
\hline \multirow{2}{*}{ Concretes } & \multicolumn{3}{|c|}{ Compressive strength (MPa) } \\
\cline { 2 - 4 } & Mean & Sd & CV (\%) \\
\cline { 2 - 4 } & \multicolumn{2}{|c|}{ Aggregate/cement ratio of 15:1 } \\
\hline 15-REF & 22.03 & 0.56 & 2.49 \\
\hline 15-R.P5 & 20.63 & 0.87 & 4.19 \\
\hline 15-R.P10 & 16.43 & 0.91 & 5.47 \\
\hline 15-R.P15 & 11.50 & 0.79 & 6.80 \\
\hline 15-R.P20 & 3.05 & 0.69 & 21.69 \\
\hline \multicolumn{4}{|c|}{ Aggregate/cement ratio of $10: 1$} \\
\hline 10-REF & 33.62 & 0.91 & 2.69 \\
\hline 10-R.P5 & 34.34 & 0.92 & 2.66 \\
\hline 10-R.P10 & 28.18 & 1.13 & 4.96 \\
\hline 10-R.P15 & 19.97 & 0.90 & 8.13 \\
\hline 10-R.P20 & 10.24 & 0.86 & 1.73 \\
\hline \multicolumn{4}{|c|}{ Aggregate/cement ratio of $6: 1$} \\
\hline 6-REF & 50.49 & 0.88 & 1.96 \\
\hline 6-R.P5 & 57.37 & 1.13 & 1.60 \\
\hline 6-R.P10 & 57.24 & 0.92 & 2.74 \\
\hline 6-R.P15 & 35.06 & 0.97 & \\
\hline 6-R.P20 & 20.84 & 0.93 & \\
\hline
\end{tabular}


With respect to the $A / C$ ratio of 15 , it should be noted that the highest value corresponded to the reference concrete. In the mix with an $\mathrm{A} / \mathrm{C}$ ratio of 10 , the concrete with an organic waste content of $5 \%$ achieved results above those of the reference concrete. For specimens with higher cement content ( $A / C$ ratio of 6 ), the concrete produced with $5 \%$ and $10 \%$ of the residual powder had higher strength values with respect to the concrete 6-REF.

Concrete made with the residue replacing cement did not show satisfactory results, as can be seen in the Table 7 . Therefore, in mixtures with a lower cement content and higher aggregate content ( $A / C$ ratio 15:1), there was a greater surface area of aggregate and, thus, more interface area. It is likely that the proportion of cement, together with each of the percentages of powder studied, did not allow the correct packaging of the cementitious matrix. We observe that replacing the cement with 5\% residual powder from organic waste improved the paste and yielded a stronger concrete. It is possible that packing the powder together with the cement particles refined the pores and decreased the amount of voids. The increase in resistance in the mixtures with $5 \%$ and $10 \%$ of the powder with an A/C ratio of 6 may be due to a denser and less porous concrete.

A statistical analysis through Analysis of Variance (ANOVA) was done to compare the mean compressive strength of the samples for each aggregate/cement ratio. The results are shown in table $A .1$ of Appendix $A$.

From ANOVA analysis it was known that $P$-value is considerably smaller than $\alpha=0.05$, therefore, $H_{O}$ (null hypotheses) is not true for the three mixtures (15:1, 10:1 and 6:1). In this way, one can conclude that residual powder as a cement replacement significantly affects the mean compressive strength of the concrete.

According to the results obtained in the 10:1 and 6:1 traces can be inferred that the organic residue powder acted as filler in the concrete making it possible to fill the voids between the dispersed cement particles, promoting an increase in the compactness of the mixture and, consequently, the pore refinement. This same behavior was found by Rebmann (2011) in his research on low cement concrete. Based on the concepts of aggregate packaging and the use of fillers in the cement paste, high strength concretes were obtained with cement reduction up to $30 \%$.

Corinaldesi et al. (2010) evaluate the effects of the marble powder in mortar and concrete. In terms of mechanical performance, $10 \%$ substitution of sand by the marble powder in the presence of a superplasticizing admixture provided maximum compressive strength at the same workability level, comparable to that of the reference mixture after 28 days of curing. Moreover, an even more positive effect of marble powder is evident at early ages, due to its filler ability.
Felekoğlu et al. (2006) studied the effect of fly ash and limestone fillers on the compressive strength of selfcompacting repair mortars. The results derived from compressive strength tests showed that both limestone fillers were more effective than fly ash in terms of early strength gain. However, beyond 28 days, mixes incorporating fly ash gave higher strength values than the control mixtures due to the pozzolanic effect of fly ash.

\section{Conclusions}

This paper proposes to investigate the feasibility of using the residual powder obtained from organic waste for replacing a part of Portland cement during concrete production. His scientific contribution is the development of an alternative material for achieving sustainability in the construction industry due to these conclusions:

- The residual powder from organic waste for his source has very low concentrations of heavy metals and, therefore, can be safely handled.

- The powder is composed of small particles of varying size and shape, allowing it to fill voids in the cement paste.

- In the concrete mix, the degree of successful performance varies based on the $\mathrm{A} / \mathrm{C}$ ratio and the proportion of powder residue replacing the cement.

- In concrete with low cement consumption, the powder was not correctly packed in the cement matrix, possibly due a greater number of aggregates and a higher surface area in the mixture.

- In mixtures with an average consumption, the concrete with 5\% powder showed higher compressive strength than the reference concrete. The result was a denser concrete, with lower absorption and voids.

- In mixtures rich in cement, the replacement of powder up to $10 \%$ yielded the best mechanical behavior of the concrete. Therefore, correct packaging of the powder allows the filling of voids and the refining of the pores of the cement paste.

- It is possible to offer an alternative to the discarding of organic waste by transforming it into a reusable powder that can be used as filler to replace a portion of the cement in concrete.

- It is important, in future, to study and evaluate the durability of concrete incorporating residual powder from organic waste, the pozzolanic reactivity of these materials with the cement and the volumetric changes that occur in the mixture. 
Table A.1. ANOVA test for compressive strength of the concrete for 15:1 aggregate/cement ratio. (Self-Elaboration)

\begin{tabular}{|c|c|c|c|c|c|}
\hline $\begin{array}{c}\text { Source of } \\
\text { Variation }\end{array}$ & Sum of Squares & $\begin{array}{c}\text { Degrees of } \\
\text { Freedom }\end{array}$ & $\begin{array}{c}\text { Mean } \\
\text { Square }\end{array}$ & $\boldsymbol{F}$ & P-value \\
\hline Columns & 1912.69 & 4 & 478.17 & 826.45 & $4.14 E-34$ \\
\hline Error & 20.25 & 35 & 0.58 & & \\
\hline Total & 1932.94 & 39 & & & \\
\hline
\end{tabular}

Table A.2. ANOVA test for compressive strength of the concrete for 10:1 aggregate/cement ratio. (Self-Elaboration)

\begin{tabular}{|c|c|c|c|c|c|}
\hline $\begin{array}{c}\text { Source of } \\
\text { Variation }\end{array}$ & Sum of Squares & $\begin{array}{c}\text { Degrees of } \\
\text { Freedom }\end{array}$ & $\begin{array}{c}\text { Mean } \\
\text { Square }\end{array}$ & F & P-value \\
\hline Columns & 3324.19 & 4 & 831.05 & 933.27 & $5.04 E-35$ \\
\hline Error & 31.17 & 35 & 0.89 & & \\
\hline Total & 3355.36 & 39 & & & \\
\hline
\end{tabular}

Table A.3. ANOVA test for compressive strength of the concrete for 6:1 aggregate/cement ratio. (Self- Elaboration)

\begin{tabular}{|c|c|c|c|c|c|}
\hline $\begin{array}{c}\text { Source of } \\
\text { Variation }\end{array}$ & Sum of Squares & $\begin{array}{c}\text { Degrees of } \\
\text { Freedom }\end{array}$ & $\begin{array}{c}\text { Mean } \\
\text { Square }\end{array}$ & F & P-value \\
\hline Columns & 8102.52 & 4 & 2025.63 & 2378.99 & $4.32 E-42$ \\
\hline Error & 29.80 & 35 & 0.85 & & \\
\hline Total & 8132.32 & 39 & & & \\
\hline
\end{tabular}

\section{References}

NBR NM 23 (2001), Cimento Portland e outros materiais em pó: Determinação da massa específica. Rio de Janeiro: Associação Brasileira de Normas Técnicas.

NBR. NM 52 (2009), Agregado miúdo. Determinação da massa específica e massa específica aparente. Rio de Janeiro: Associação Brasileira de Normas Técnicas. 2009.

NBR NM 30 (2001), Agregado miúdo - Determinação da absorção de água. Rio de Janeiro: Associação Brasileira de Normas Técnicas.

NBR NM 45 (2006), Agregados - Determinação da massa unitária e do volume de vazios. Rio de Janeiro: Associação Brasileira de Normas Técnicas.

NBR NM 53 (2009), Agregado graúdo: Determinação da massa específica, massa específica aparente e absorção de água. Rio de Janeiro; 2009. NBR NM 248 (2003), Agregados: Determinação da composição granulométrica. Rio de Janeiro: Associação Brasileira de Normas Técnicas.

NBR 5739 (2007), Concreto: Ensaios de compressão de corpos-de-prova cilíndricos. Rio de Janeiro: Associação Brasileira de Normas Técnicas.

NBR 7211 (2009), Agregados para concreto: Especificação. Rio de Janeiro: Associação Brasileira de Normas Técnicas.

NBR 9778 (2005), Argamassas e concretos endurecidos: Determinação da absorção de água por imersão, índice de vazios e massa Rio de Janeiro: Associação Brasileira de Normas Técnicas.

NBR 10004 (2004), Resíduos sólidos:Classificação. Rio de Janeiro: Associação Brasileira de Normas Técnicas. 
NBR 11579 (2012), Cimento Portland: Determinação do índice de finura por meio da peneira $75 \mu m$ ( ${ }^{\circ}$ 200). Rio de Janeiro: Associação Brasileira de Normas Técnicas.

Ali M. B., Saidur R., Hossain M. S. (2011), A review on emission analysis in cement industries. Renewable and Sustainable Energy Reviews, v. 15 , n. 5, p. 2252-2261.

Bernades A. et al. (2008), Quantificação e classificação dos resíduos da construção e demolição coletados no município de Passo Fundo, RS. Ambiente Construído, v. 8, n. 3, p. 65-76.

Carneiro M. S. (2013), Processo otimizado de beneficiamento de lixo urbano. BRPI1004545 (A2) .

Corinaldesi V., Moriconi G., Naik T. R. (2010), Characterization of marble powder for its use in mortar and concrete. Construction and building materials, v. 24, n. 1, p. 113-117.

Elyamani H. E., Abd Elmoaty A. E. M., Mohamed B. (2014), Effect of filler types on physical, mechanical and microstructure of self compacting concrete and Flow-able concrete. Alexandria Engineering Journal, v. 53, n. 2, p. 295-307.

Felekoglu B. et al. (2006), The effect of fly ash and limestone fillers on the viscosity and compressive strength of self-compacting repair mortars. Cement and concrete research, v. 36, n. 9, p. 1719-1726.

Ferraris M. et al. (2009), Use of vitrified MSWI bottom ashes for concrete production. Waste Management, v. 29, n. 3, p. 1041-1047.

Goyal S., Dhull S. K., Kapoor K. K. (2005), Chemical and biological changes during composting of different organic wastes and assessment of compost maturity. Bioresource Technology, v. 96, n. 14, p. 1584-1591.

Lagerblad B., Vogt C. (2008), Fillers and ultrafine fillers to save cement and improve concrete properties. Proceedings of 8th International Symposium on Utilization of High Strength and High Performance Concrete, p.168-176.

Rebmann M. (2011), Durabilidade de concretos estruturais com baixo consumo de cimento Portland e alta resistência. Dissertação, Mestrado. Departamento de Estruturas, Escola de Engenharia de São Carlos, Universidade de São Paulo, São Carlos - SP, 211 p.

Montgomery D. C., Runger G. C. (2010), Applied statistics and probability for engineers. John Wiley \& Sons, 2010. ISBN 0470053046.

Saikia N., Kato S., Kojima T. (2007), Production of cement clinkers from municipal solid waste incineration (MSWI) fly ash. Waste Management, v. 27, n. 9, p. $1178-1189$.

Shi H.-S., Kan L.-L. (2009), Leaching behavior of heavy metals from municipal solid wastes incineration (MSWI) fly ash used in concrete. Journal of Hazardous Materials, v. 164, n. 2-3, p. 750-754.

Vogt C. (2010), Ultrafine particles in concrete. PhD Thesis. Royal Institute of Technology, Stockholm, Sweden.

Wu K. et al. (2012), Preparation of alinite cement from municipal solid waste incineration fly ash. Cement \& Concrete Composites, v. 34, n. 3, p. 322-327. 